\title{
KEMANDIRIAN PETANI DALAM PENERAPAN PENGENDALIAN HAMA TERPADU PADI SAWAH (Oryza sativa. $L$ )
}

\author{
Yandri Muhamad Ramadan ${ }^{* 11}$, Achdiyat ${ }^{2)}$, Tri Ratna Saridewi ${ }^{3)}$ \\ 1,2,3) Politeknik Pembangunan Pertanian Bogor \\ ${ }^{*}$ Penulis Korespondensi, E-mail: usyandrimuhamadramadan@gmail.com
}

\begin{abstract}
ABSTRAK
Pengendalian Hama Terpadu (PHT) sudah dikenalkan kepada petani oleh penyuluh melalui program SLPHT dan pembinaan lanjutan untuk melatih petani agar mandiri dalam menerapkan PHT. Kenyataannya, tercatat dalam programa tingkat Desa Sukalarang Kecamatan Sukalarang Tahun 2020 baru 51\% telah melaksanakan pengendalian hama dan penyakit secara terpadu, sisanya $49 \%$ belum menerapkan pengendalian hama dan penyakit secara terpadu. Pengkajian ini dilakukan untuk mengetahui tingkat kemandirian petani, dan menganalisis pengaruh faktor internal dan eksternal terhadap kemandirian petani dalam penerapan pengendalian hama terpadu tanaman padi sawah. Pengkajian ini dilakukan dengan menggunakan pendekatan survey, dan analisis data yang digunakan yaitu analisis deskriptif dan uji Regresi Linier Berganda. Berdasarkan hasil pengkajian dari 40 orang sampel responden, 15 orang $(37,5 \%)$ berada pada tingkat kemandirian rendah, 21 orang $(52,5 \%)$ responden berada pada tingat kemandirian sedang, sedangkan 4 orang $(10 \%)$ responden berada pada tingkat kemandirian tinggi. Faktor yang berpengaruh terhadap secara signifikan kemandirian petani yaitu peran kelompok tani $(0,003<0,5)$. Strategi berupa penyuluhan dan pembinaan untuk peningkatan kemandirian petani harus dilakukan.
\end{abstract}

Kata kunci: Kemandirian petani; Pengendalian hama terpadu; Padi sawah; SLPHT; Kelompok tani

\section{PENDAHULUAN}

Kecamatan Sukalarang merupakan salah satu penyumbang produksi padi sebanyak 8.755 ton dari luas panen 1.452 ha di Kabupaten Sukabumi, dengan rata-rata hasil per hektar 60,31 kwintal/ha (BPS Kabupaten Sukabumi dalam Angka, 2019). Angka produksi tersebut mengalami penurunan dari tahun sebelumnya, dari total produksi 10.498 ton/1.721 ha menjadi 8.755 ton/1.452 ha (BPS Kabupaten Sukabumi dalam Angka, 2018). Salah satu permasalahan yang mempengaruhi penurunan produksi tersebut yaitu penerapan pengendalian hama dan peyakit yang masih rendah (Programa Desa Sukalarang, 2020).

Pada dasarnya Pengendalian Hama Terpadu (PHT) sudah dikenali petani melalui program SL-PHT (Sekolah Lapang Pengendalian Hama Terpadu), dimana seharusnya petani setempat dapat menerapkan pengendalian hama dengan baik dan mandiri. Faktanya dilapangan hanya sebagian petani yang menerapkan pengendalian hama, itu pun tidak secara keseluruhan menerapakan sistem pengendalian hama terpadu yang telah diperolehnya pada saat kegiatan SLPHT. Berdasarkan hasil identifikasi, sebagian besar petani akan bergerak apabila ada dorongan dan bantuan, tentunya hal ini menjadi kebiasaan yang kurang baik. Berkaitan dengan permasalahan tersebut, kemandirian petani dituntut dalam penerapan PHT secara berkelanjutan dan kontinuitas. Menurut Aprolita et al, (2008) mengemukakan bahwa masyarakat dikatakan mandiri jika telah 
dapat menolong dirinya sendiri, dalam mengidentifikasi masalah dan mencari jalan keluar cara penyelesaiannya. Covey (2010) menegaskan bahwa kemandirian itu merupakan bagian dari kontinum kematangan yang berkembang dari ketergantungan individu (dependence), menuju keberdayaan (independence), dan berpuncak pada kemandirian (interrelational) atau saling tergantungan (interdependence). Teknologi usahatani padi sudah lama diperkenalkan kepada petani, namun belum dimafaatkan secara optimal, hal ini disebabkan masih tingginya tingkat kepercayaan petani melakukan pengelolaan usahatani padi secara turun temurun dan menggunakan teknologi yang terbatas (Khairunnisa, et al., 2019). Kemudian Toha dan Musyadar (2014) mengmukakan bahwa petani mandiri adalah petani yang memiliki pembinaan diri yang baik, manajemen yang baik, dan sosial yang baik. Rendahnya petani dalam menerapkan pengendalian hama terpadu, secara tidak langsung akan mempengaruhi produktivitas hasil usahatani padi sawah, maka perlu adanya analisis mengenai tingkat kemandirian petani dalam penerapa pengendalian hama terpadu. Tujuan dari penelitian yaitu: 1) Mendeskripsikan tingkat kemandirian petani dalam penerapan Pengendalian Hama Terpadu (PHT) Padi Sawah di Kecamatan Sukalarang Kabupaten Sukabumi, 2) Menganalisis pengaruh faktor internal dan faktor eksternal terhadap kemandirian petani dalam penerapan Pengendalian Hama Terpadu (PHT) Padi Sawah di Kecamatan Sukalarang Kabupaten Sukabumi, 3) Merumuskan strategi penyuluhan untuk pengembangan kemandirian petani dalam penerapan Pengendalian Hama Terpadu (PHT) Padi Sawah di Kecamatan Sukalarang Kabupaten Sukabumi.

\section{METODE}

Kegiatan penelitian ini dilaksanakan di Desa Sukalarang Kecamatan Sukalarang Kabupaten Sukabumi Provinsi Jawa Barat. Lokasi ditentukan berdasarkan potensi dan keadaan yang sesuai dengan tema penelitian. Sebagian besar di Desa Sukalarang memiliki komoditas unggulan padi sawah, dan terdapat kelompok tani yang pernah mengikuti SLPHT. Populasi berasal dari Kelompok tani Tani Mukti yang beranggotakan 40 orang dan semuanya pernah mengikuti kegiatan Sekolah Lapang Pengendalian Hama Terpadu (SL-PHT). Metode pengambilan sampel yang digunakan yaitu dengan metode sensus. Metode sensus merupakan cara pengumpulan data atau responden apabila seluruh populasi diselidiki satu persatu (Sholeh et al, 2019). Teknik yang digunakan dalam pengumpulan data pada penelitian ini yaitu dengan teknik observasi, penyebaran dan pengisian kuesioner, dan wawancara. Adapun data primer diperoleh langsung dari petani yang pernah mengikuti kegiatan Sekolah Lapang Pengendalian Hama Terpadu (SL-PHT) pada tanaman padi sawah, tokoh masyarakat, dan penyuluh pertanian wilayah binaan. Data sekunder sendiri diperoleh tidak langsung, melalui lembaga atau instansi setempat yang memang berkaitan dan menunjang dalam pemenuhan kebutuhan data pengkajian.

\section{Teknik Analisis Data}

Analisis data yang digunakan dalam menjawab tujuan pertama yaitu cara deskriftif, yaitu mendeskripsikan tingkat kemandirian petani dalam penerapan pengendalian hama terpadu (PHT) padi sawah. Kemudian untuk mengkelaskan tingkatan kemandirian petani dilakukan dengan menghitung panjang kelas interval dengan menggunakan rumus :

$$
=\frac{(\text { umlah soal } \times \text { nilai tertinggi })-(\text { Jumlah soal } \times \text { nilai terendah })}{\text { Kategori }}
$$

Selanjutnya, untuk menjawab tujuan yang kedua menggunakan analisis regresi linier berganda yaitu menganalisis pengaruh faktor internal (X.1) dan faktor eksternal (X.2) terhadap kemandirian petani dalam penerapan pengendalian hama terpadu (PHT) padi sawah (Y.1) dengan taraf kepercayaan yang digunakan yaitu 95\% dan taraf kesalahannya 
$(\alpha=5 \%)$. Data yang disediakan pada penelitian ini yaitu skala ordinal yang menggunakan ukuran berjenjang dan tidak memiliki dimensi kuantitatif: 1. Tidak pernah; 2. Pernah; 3. Kadang-kadang; 4. Sering; yang dikonversikan menjadi data interval dengan menggunakan MSI (Methode Successive Interval) (Muhidin dan Abdurahman, 2007). Pengolahan konversi data ordinal ke interval menggunakan program Microsoft Excel 2010. Menurut Burhan (2004) dalam Wijaya (2018) model persamaan yang digunakan untuk dua variable bebas adalah sebagai berikut:

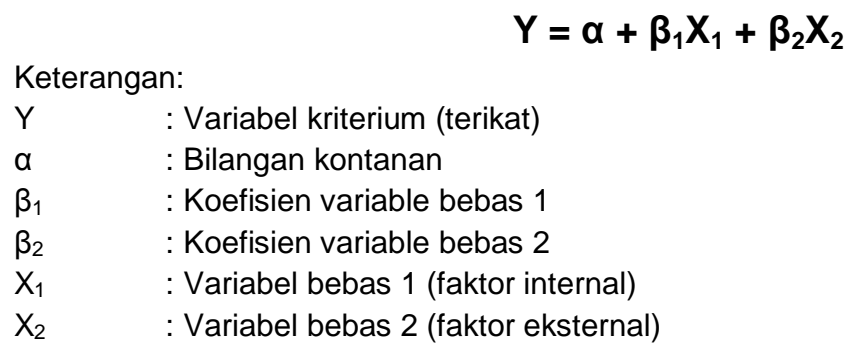

Straetgi yang digunakan untuk meningkatkan kemandirian petani dalam penerapan pengendalian hama terpadu (PHT) padi sawah ditentukan berdasarkan hasil deskripsi dari tingkat kemandirian petani dan hasil analisis faktor internal dan ekssternal yang mempengaruhi kemandirian petani dalam penerapan pengendalian hama terpadu (PHT).

\section{Hipotesis}

Hipotesis dalam penelitian ini yaitu hipotesis nol $(\mathrm{H} 0)$ dan hipotesis alternatif $(\mathrm{H} 1)$. $\mathrm{H} 0$ dinyatakan dalam kalimat negatif, sedangkan $\mathrm{H} 1$ dinyatakan dalam kalimat positif, maka dapat dinyatakan dalam kalimat berikut :

$\mathrm{H}_{0} \quad$ : Tidak terdapat pengaruh yang signifikan variabel independen $(X)$ terhadap variabel dependen $(\mathrm{Y})$

$\mathrm{H}_{1} \quad$ : Terdapat pengaruh yang signifikan variabel independen $(\mathrm{X})$ terhadap variabel dependen $(\mathrm{Y})$

Pengujian hipotesis tersebut menggunakan analisis regresi berganda dengan tingkat kesalahan $10 \%$, dengan artian jika nilai sig. $<0,05$ maka $\mathrm{H}_{0}$ ditolak. Begitupun sebaliknya jika nilai sig. > 0,05 maka $\mathrm{H}_{0}$ diterima.

\section{HASIL DAN PEMBAHASAN}

Luas Kecamatan Sukalarang adalah $2.211,00$ ha. Berdasarkan wilayah administrasi Kecamatan Sukalarang terdiri dari 6 desa, 24 dusun, 49 RW, dan 207 RT. Wilayah Kecamatan Sukalarang berada dikaki Gunung Gede yang berada pada ketinggian antara 500-1000 mdpl. Bentuk wilayah Kecamatan Sukalarang pada permukaan terdiri dariperbukitan dan pegunungan. Kemiringan lereng wilayah Kecamatan Sukalarang terdiri dari lahan dengan kemiringan antara 3-8\% yang terdapat dibagian selatan wilayah Kecamatan Sukalarang, kemiringan antara $25-40 \%$ terdapat dibagian tengah, dan $>40 \%$ terdapat dibagian utara wilayah Kecamatan Sukalarang. Jenis tanah di Kecamatan Sukalarang terdiri dari Latosol coklat, Asosiasi andosol, dan Regosol coklat.

Keadaan iklim di Kecamatan Sukalarang masih dipengaruhi keadaan iklim secara regional wilayah Kabupaten Sukabumi yang beriklim topis basah dengan curah hujannya sangat dipengaruhi oleh angina muson yang bertiup dari dataran Australia dan Asia. Keadaan curah hujan di Kecamatan Suklarang setiap tahunnya rata-rata sebesar 1,613 $\mathrm{mm} /$ tahun. Banyaknya hari hujan setiap tahunnya adalah 81 hari dan suhu udara berkisar antara $180 \mathrm{o}-310 \mathrm{C}$.

\section{Karakteristik Responden}

Karakteristik responden merupakan faktor internal yang mencirikan atau mengidentitaskan seorang individu, biasanya mempengaruhi individu tersebut dalam 
pengambilan keputusan dan kemandirian dari individu tersebut. Secara detail, karakteristik responden yang dianalisis adalah sebagai berikut :

Table. 1. Ringkasan Profil Demografi Responden

\begin{tabular}{|c|c|c|c|c|}
\hline No & Karakterisitik & Kategori & Jumlah & Persentase (\%) \\
\hline \multirow[t]{4}{*}{1} & Umur & Muda ( $\leq 30$ tahun) & 0 & 0 \\
\hline & & Sedang (31-60 tahun) & 32 & 80 \\
\hline & & Tua ( $\geq 61$ tahun) & 8 & 20 \\
\hline & & Jumlah & 40 & 100 \\
\hline \multirow[t]{6}{*}{2} & Tingkat Pendidikan & Tidak Lulus SD & 1 & 2,5 \\
\hline & & Lulus SD & 30 & 75 \\
\hline & & Lulus SLTP & 5 & 12,5 \\
\hline & & Tidak Lulus SLTA & 1 & 2,5 \\
\hline & & Lulus SLTA & 3 & 7,5 \\
\hline & & Jumlah & 40 & 100 \\
\hline \multirow[t]{4}{*}{3} & Lama Berusahatani & Baru ( $\leq 13$ tahun) & 2 & 5 \\
\hline & & Lama (14-35 tahun) & 32 & 80 \\
\hline & & Sangat Lama ( $\geq 36$ tahun) & 6 & 15 \\
\hline & & Jumlah & 40 & 100 \\
\hline \multirow[t]{4}{*}{4} & Luas Lahan & Kecil $(<0,5$ ha $)$ & 17 & 42,5 \\
\hline & & Sedang $(0,5-1$ ha) & 15 & 37,5 \\
\hline & & Luas ( $>1$ ha) & 8 & 20 \\
\hline & & Jumlah & 40 & 100 \\
\hline \multirow[t]{4}{*}{5} & Pengetahuan & Rendah & 0 & 0 \\
\hline & & Sedang & 8 & 20 \\
\hline & & Tinggi & 32 & 80 \\
\hline & & Jumlah & 40 & 100 \\
\hline
\end{tabular}

Sumber: Data primer, diolah 2020

Profil responden pada Tabel 1 merupakan hasil pengumpulan data berupa kuesioner dan tanya jawab untuk mencari informasi yang dibutuhkan pada penelitian ini. Karakteristik yang diukur merupakan karakteristik yang dipilih dan dianggap dapat meberikan pengaruh terhadap kemandirian petani dalam penerapan pengendalian hama terpadu. Hasil menyatakan bahwa umur petani responden 32 atau $80 \%$ berada pada kategori sedang (31-60 tahun), tingkat pendidikan 30 atau $75 \%$ lulus SD, lama berusahatani 32 atau $80 \%$ berada pada kategori lama (14-35 tahun), luas lahan 17 atau $42,5 \%$ berada pada kategori kecil $(<0,5 \mathrm{ha})$, dan pengetahuan petani terhadap PHT 32 atau $80 \%$ berada pada kategori tinggi.

\section{Penilaian Petani mengenai Peran Kelompok Tani terhadap Kemandirian Petani dalam Penerapan PHT}

Peran kelompok tani dalam membangun suatu kemandirian petani memang cukup besar, karena kelompok merupakan wadah atau forum tempat mereka mencari berbagai informasi dan melakukan interaksi sosial yang tujuan melatih petani untuk mendiri. Managemen dan sosial akan ditemukan dalam suatu kelompok.

Tabel 2. Peran Kelompok Tani terhadap Kemandirian Petani

\begin{tabular}{clcc}
\hline No & Kategori Peran Kelompok Tani & Banyak Sampel (n) & Persentase (\%) \\
\hline 1. & Rendah & 22 & 55 \\
2. & Sedang & 16 & 40 \\
3. & Tinggi & 2 & 5 \\
\hline & Jumlah & $\mathbf{4 0}$ & $\mathbf{1 0 0}$
\end{tabular}

Sumber: Data primer, diolah 2020

Penilaian petani mengenai peran kelompok tani pada penerapan pengendalian hama terpadu bahwa lebih banyak responden menilai peran penyuluh adalah rendah, sedangkan hanya sedikit responden menilai peran kelompok tani pada kategori tinggi. 
Peran kelompok tani yang dimaksudkan yaitu peran kelompok yang membantu petani dalam segi penyediaan, pengelolaan sarana produksi terutama dalam pengendalian hama dan intensitas petani dalam mengikuti kegiatan kelompok. Berdasarkan informasi yang diperoleh dari hasil wawancara, bahwa kelompok tani hanya menyediakan pinjaman alat hasil dari bantuan dan swadaya petani yang dikelola oleh kelompok, sehingga tidak secara keseluruhan kelompok memenuhi kebutuhan petani dalam pengendalian hama terpadu. Kemudian petani ikut serta aktif dalam kegiatan kelompok apabila ada program saja, kegiatan rutin kelompok jarang sekali berpartisipasi.

\section{Penilaian Petani mengenai Peran Penyuluh Pertanian terhadap Kemandirian Petani dalam Penerapan PHT}

Peran penyuluh dalam membentuk suatu kemandirian petani sangatlah berarti. Berdasarkan penilaian petani mengenai peran penyuluh pada penerapan pengendalian hama terpadu lebih banyak responden menilai peran penyuluh adalah rendah. Berdasarkan hasil tersebut secara garis besar masih rendahnya peran penyuluh dalam menumbuhkan dan membina kemandirian petani.

Tabel 3. Peran Penyuluh terhadap Kemandirian Petani

\begin{tabular}{clcc}
\hline No & Kategori Peran Penyuluh & Banyak Sampel (n) & Persentase (\%) \\
\hline 1. & Rendah & 28 & 70 \\
2. & Sedang & 12 & 30 \\
3. & Tinggi & 0 & 0 \\
\hline & Jumlah & $\mathbf{4 0}$ & $\mathbf{1 0 0}$ \\
\hline
\end{tabular}

Sumber: Data primer, diolah 2020

Hasil penelitian ini berbeda dengan Wardani dan Anwarudin (2018) mayoritas petani menilai peran penyuluh tinggi, hal tersebut dikarenakan perbedaan faktor dari penyuluh pertanian itu sendiri dalam melaksanakan tugasnya, dan hampir merata pada semua tugasnya. Informasi yang diperoleh dari wawancara langsung kepada petani, penyuluh bergerak aktif apabila terdapat program dan selama program tersebut berlangsung. Selepas program selesai intensitas penyuluh dalam membina petani berkurang, terutama dalam hal monitoring dan evaluasi terhadap hasil program tersebut. Subejo (2009) dalam Indraningsih (2011) penyuluh pertanian dituntut untuk tidak sekedar berperan sebagai penyampai (diseminator) teknologi dan informasi, akan tetapi lebih menuju kearah sebagai motivator, dinamisator, pendidik, fasilitator, dan konsultan bagi petani. Maka dari itu penyuluh pertanian harus menguasai segala bentuk maupun hal lainnya dan memanfaatkan teknologi informasi, komunikasi dan edukasi dalam menjalankan tugasnya.

\section{Tingkat Kemandirian Petani dalam Penerapan Pengendalian Hama Terpadu pada Tanaman Padi Sawah}

Berdasarkan program tingkat Desa Sukalarang Kecamatan Sukalarang Tahun 2020 dapat diketahui bahwa terdapat permasalahan yaitu masih rendahnya tingkat penerapan pengendalian hama. Tercatat baru 51\% telah melaksanakan pengendalian hama dan penyakit secara terpadu, sisanya $49 \%$ belum menerapkan pengendalian hama dan penyakit secara terpadu. Permasalahan tersebut dikaitkan dengan kemandirian petani dalam penerapan pengendalian hama secara terpadu yang masih rendah. Pada dasarnya segala hal mengenai pengendalian hama secara terpadu sudah di berikan pada kegiatan SL-PHT secara kompleks. Namun, pada kenyataannya tidak demikian, masih banyak petani yang tidak menerapkan pengendalian hama secara terpadu.

Petani mandiri akan tersendirinya dengan kesadarannya melaksanakan pengendalian hama secara terpadu, begitupun kebalikannya petani yang tidak mandiri akan acuh dan pengendalian tidak sesuai aturan yang berdampak terhadap produksi. Pengukuran tingkat kemandirian petani dilakukan kepada petani sebagai responden sebanyak 40 orang dari kelompok tani Tani Mukti di Desa Sukalarang Kecamatan 
Sukalarang. Kelompok tani tersebut pernah mengikuti kegiatan SL-PHT, dan hanya kelompo tani Tani Mukti di Desa Sukalarang yang pernah mengikuti SL-PHT.

Tabel 4. Tingkat Kemandirian Petani dalam Penerapan Pengendalian Hama Secara Terpadu Tanaman Padi Sawah

\begin{tabular}{clcc}
\hline No & Kategori Kemandirian Petani & Banyak Sampel (n) & Persentase (\%) \\
\hline 1. & Rendah & 15 & 37,5 \\
2. & Sedang & 21 & 52,5 \\
3. & Tinggi & 4 & 10 \\
\hline \multicolumn{2}{c}{ Jumlah } & $\mathbf{4 0}$ & $\mathbf{1 0 0}$ \\
\hline \multicolumn{2}{c}{ Sumber: Data primer, diolah 2020 }
\end{tabular}

Kemandirian petani yang diukur yaitu mengenai pembinaan diri, manajemen, dan sosial (Toha dan Musyadar, 2014). Tentunya pembinaan diri, manajemen, dan sosial mengenai penerapan pengendalian hama secara terpadu sesuai dengan apa yang telah diperoleh responden pada saat kegiatan SL-PHT. Hasil pengukuran menerangkan bahwa 15 orang atau $37,5 \%$ berada pada tingkat kemandirian rendah, 21 orang atau $52,5 \%$ responden berada pada tingat kemandirian sedang, sedangkan 4 orang atau $10 \%$ responden berada pada tingkat kemandirian tinggi. Hal tersebut dikarenakan pengetahuan petani mengenai pengendalian hama terpadu sebagian besar (80\%) berada pada kategori tinggi dan sisanya $(20 \%)$ berada pada kategori sedang. Hasil wawancara dan diskusi, petani dapat dikatakan masih mengingat materi yang diperolehnya pada saat kegiatan SLPHT. Hal tersebut selaras dengan penelitian yang dilakukan oleh Sulistiyono et al (2008) bahwa petani yang mengikuti Sekolah Lapang Pengendalian Hama Terpadu (SLPHT) memiliki tingkat pengetahuan lebih tinggi mengenai pengendalian hama terpadu dibandingkan dengan petani yang tidak mengikuti kegiatan SLPHT. Burhansyah (2014) mengatakan bahwa tingkat pendidikan seseorang sangat berpengaruh terhadap kemampuan seseorang tersebut dalam menyerap teknologi dan informasi. Senada dengan pernyataan Rahaman et al (2018) petani yang berpendidikan lebih cepat menerima praktik pertanian yang direkomendasikan dari pada rekan-rekan mereka yang tidak berpendidikan. Tidak dapat kita pungkiri bahwa setinggi atau rendahnya pendidikan penerimaan teknologi tergantung kebutuhan dan keinginan petani sendiri, karena percuma apabila pendidikan tinggi namun tidak menerima teknologi informasi yang disampaikan karena tidak berhubungan dengan kebutuhannya. Hal ini selaras dengan pernyataan Astuti dan Honorita (2014) apabila tingkat pengetahuan tinggi dan disertai dengan sikap positif individu tersebut terhadap suatu informasi maupun teknologi baru khususnya dibidang pertanian maka penerapan teknologi tersebut akan menjadi lebih efektif, dan pada akhirnya dapat memberikan hasil yang lebih memuaskan secara kualitas maupun kuantitas. Selanjutnya didukung dengan pernyataan Irawan dan Suparmoko (1992) dalam Sumilah dan M. Ichwan (2017) bahwa pengetahuan petani merupakan produk hasil dari pengalaman dan kemampuan partisipasi petani yang dapat membekali petani agar dapat melaksanakan manajemen usahatani dengan baik menuju usahatani yang efisien. Fadhilah, Eddy dan Gayatri (2018) mengungkapkan bahwa petani yang mempunyai pengetahuan yang banyak akan mendukung dalam menentukan keputusan karena pengetahuan menjadi elemen dasar bagi petani dalam adopsi inovasi.

Kemudian didukung dengan umur petani yang berada pada usia produktif yaitu 3160 tahun dan pengalaman berusahatani yang lama yaitu 14-35 tahun. Setiawan (2010) berpendapat bahwa produktivitas kerja dikaitkan dengan tingkatan usia yang produktif, karena golongan usia muda lebih produktif dibandingkan dengan golongan usia tua. Seperti halnya yang terjadi pada responden dalam pengkajian ini sebagian besar berada pada golongan usia produktif. Penduduk yang berada pada golongan usia produktif adalah penduduk yang termasuk kedalam golongan usia antara 15-64 tahun (Sukmaningrum, 2017). Sari et al (2016) mengungkapkan bahwa umur memiliki peran yang penting dalam menggapai keberhasilan usaha karena umur akan mempengaruhi daya ingat, produktivitas, keberanian untuk mengambil resiko dan pola piker dalam 
menerima inovasi dalam berusahatani. Sebagian besar petani memiliki pengalaman berusahatani yang cukup lama, dengan demikian hal ini lah yang dapat mempengaruhi tingkat pengetahuan petani. Pernyataan tersebut senada dengan Prastia, et al., (2016) semakin lama petani melakukan kegiatan bertani, maka semakin banyak pengetahuan yang diperoleh dari pengalaman yang didapatkannya dan pengalaman dalam keikutsertaan petani dalam kegiatan penyuluhan dan pelatihan. Semakin lama seseorang dalam berusahatani, maka pengalaman berusahatanipun semakin banyak. Pengalaman dijadikan sebuah pelajaran untuk pengambilan keputusan dalam mengambil suatu tindakan. Pernyataan tersebut selaras dengan pernyataan Haque et al (2016) pengalaman dalam bertani padi merupakan faktor penting dalam mengadopsi penerapan PHT. Meskipun demikian, peningkatan kemandirian petani dalam penerapan PHT masih harus dilakukan peningkatan, agar penerapan PHT lebih efektif dan secara menyeluruh. Faktor eksteral seperti kelompok tani dalam hal ini mempunyai peransebagai wadah atau forum bagi petani, membentuk kedewasaaan dan kemandirian petani sendiri. Serta bantuan peran penyuluh sebagai pembimbing dan membantu petani dalam proses penyebaran teknologi informasi kepada petani.

\section{Pengaruh Faktor Interal dan Eksternal terhadap Kemandirian Petani dalam Penerapan Pengendalian Hama Terpadu pada Tanaman Padi Sawah}

Faktor internal atau karakterisitk responden yang berhasil didapat untuk dianalisis yaitu umur, tingkat pendidikan, lama berusaha tani, luas lahan, pengetahuan terhadap pengendalian hama terpadu, dan faktor eksternal terdiri dari peran kelompok tani dan peran penyuluh. Berikut adalah hasil pengujian secara statistik sebagaimana ditunjukkan dalam Tabel 5.

Tabel 5. Faktor Internal dan Ekternal yang Berpengaruh terhadap Kemandirian Petani

\begin{tabular}{|c|c|c|c|c|}
\hline Model & $\mathbf{R}^{2}$ & Sig. F & Sig. & Keterangan \\
\hline (Constant) & & & 0,786 & Tidak Berpengaruh \\
\hline Umur (X1.1) & & & 0,388 & Tidak Berpengaruh \\
\hline Tingkat Pendidikan (X1.2) & & & 0,342 & Tidak Berpengaruh \\
\hline Lama Usaha Tani (X1.3) & 0555 & مחم ח & 0,261 & Tidak Berpengaruh \\
\hline Luas Lahan (X1.4) & U,०0৩ & 0,000 & 0,542 & Tidak Berpengaruh \\
\hline Pengetahuan (X1.5) & & & 0,100 & Tidak Berpengaruh \\
\hline Peran Poktan (X2.1) & & & 0,003 & Berpengaruh \\
\hline Peran Penyuluh (X2.2) & & & 0,302 & Tidak Berpengaruh \\
\hline
\end{tabular}

Sumber: Data primer, diolah 2020

Berdasarkan hasil analisis bahwa faktor internal dan faktor eksternal memberikan pengaruh terhadap kemandirian petani dalam penerapan pengendalian hama terpadu padi sawah (Oryza sativa. L) (Sig. 0,000). Selanjutnya, nilai koefisien determinasi sebesar 0,555; hal tersebut dapat diartikan bahwa umur, tingkat pendidikan, lama berusahatani, luas lahan, pengetahuan, peran kelompok tani, dan peran penyuluh dapat menjelaskan kemandrian petani sebesar $55,5 \%$, sedangkan sisanya $44,5 \%$ dijelaskan atau dipengaruhi oleh variabel lain yang tidak tidak dijelaskan dalam model.

\section{Pengaruh Peran Kelompok Tani Terhadap Kemandirian Petani}

Dari Tabel 5 faktor yang berpengaruh terhadap kemandirian petani dalam penerapan pengendalian hama secara terpadu (PHT) di Desa Sukalarang Kecamatan Sukalarang Kabupaten Sukabumi yaitu peran kelompok tani (Sig. 0,003<0,05). Hasil analisis pada penelitian ini sebagian besar petani menilai peran kelompok tani terhadap kemandirian dalam penerapan PHT padi sawah ini rendah, namun tidak sedikit juga petani menilai peran kelompok tani pada kategori sedang bahkan ada yang menilai peran kelompok tani tinggi. Penilaian petani terhadap peran kelompok tani ini mengenai seberapa sering kelompok mengadakan pertemuan, sebagai forum tempat pertukaran informasi, dan tempat penyediaan dan penyimpanan sarana dan prasarana. Hal ini 
ditambahkan berdasarkan hasil penelitian yang dilakukan oleh Rahayu dan Malia (2018) bahwa kemandirian anggota kelompok tani dipengaruhi oleh peran ketua kelompok tani yang baik terhadap anggota kelompoknya. Peran ketua kelompok tani ini diluar indikator dalam model yang digunakan dalam pengkajian ini.

Peran kelompok tani merupakan salah satu faktor eksternal yang mempengaruhi kemandirian petani dalam penerapan pengendalian hama terpadu yang memiliki pengaruh yang cukup besar terhadap pembentukan kemandirian petani. Fungsi kelompok tani yang disebutkan dalam Permentan No. 67 Tahun 2016 yaitu sebagai wahana belajar, wahana kerjasama, dan unit produksi. Petani yang tergabung kedalam kelompok akan mendapatkan ilmu pengetahuan, keterampilan, memupuk rasa tanggung jawab, dan gotong royong yang pada kahirnya melatih dan menumbuhkan kemandirian itu sendiri. Seperti pendapat yang dikemukakan oleh Lestari et al (2018) fungsi kelompok tani sebagai media belajar yaitu untuk menambah pengetahuan dan keterampilan.

Fungsi kelompok tani sebagai media kerjasama yaitu membentuk rasa memiliki rasa kebersamaan, solidaritas dan kekompakan yang tinggi dalam upaya menigkatkan produktivitas. Hal ini selaras dengan yang dikemukakan oleh Nirmalawati (2013) behawa kerjasama antara anggota kelompok tani berpengaruh nyata terhadap kemandirian petani. Adanya rasa percaya diri dari setiap anggota kelompok harapannya dapat memudahkan terjalinnya suatu kerjasama sehingga akan memperkuat fungsi kelompok tani tersebut, dan harapan lainnya petani yang tergabung kedalam kelompok tani secara sendirinya terpengaruh untuk lebih berfikir maju dan mandiri, tidak bergantung terhadap bantuan pemerintah sehingga dapat menyelesaikan masalah tersebut dengan kemampuan sendiri (Elsiana et al, 2018).

Kelompok tani dalam hal ini berperan sebagai wadah dalam menerima program dan bantuan. Wadah petani dalam meningkatkan pengetahuan, keterampilan dan kemandirian mengenai pengendalian hama terpadu (PHT). Tujuan dibentuknya kelompok harus berdasarkan keinginan yang tumbuh dari setiap petani untuk menyamakan tujuan dan gotong royong, seperti yang diungkapkan Budhi et al (2009) bahwa kurang berfungsinya kelompok tersebut disebabkan karena pembentukan kelompok tersebut tidak didasari atas dasar partisipatif, karena petani sebagai peneriman manfaat yang ditempatkan sebagai pelaku yang menjalankan kelompok tersebut. Petani dijadikan sebagai objek, yang seharusnya sebagai subjek dalam kelompok tersebut. Hal ini selaras dengan pernyataan Nuryanti dan Swastika (2011) bahwa kelompok tani di Indonesia pada saat ini dibentuk tidak berasaskan atas inisiatif petani dalam memperkuat diri, akan tetapi kebanyakan sebagai respon dari program berupa bantuan yang dicanangkan pemerintah yang mana bantuan tersebut kepada kelompok, secara tidak langsung mengharuskan petani berkelompok.

Kemudian fungsi kelompok tani sebagai unit produksi yaitu agar petani mampu mengambil keputusan dalam pengembangan produksi, dimana kelompok menyediakan sarana produksi untuk memfasilitasi petani. Maka, dengan demikian akan terbentuk kemandirian baik pada tingkat kelompok maupun petani sendiri, karena manajemen dalam kelompok tani tersebut. Jafri, et al (2016) mengungkapkan bahwa upaya untuk lebih mengaktifkan kembali kelembagaan petani yaitu dengan memposisikan petani sebagai pelaku dan desainer dalam penumbuhan dan pengaktifan kembali kelembagaan tersebut, dengan memperhatikan beberapa prinsip yaitu demokratis, partisipatif, difusi inovasi, pemberdayaan, keadaan permasalahan di masyarakat, serta perbedaan orientasi setiap anggota kelompok.

\section{Petak Percontohan}

Petak percontohan ini merupakan penerapan teknologi yang menajdi tema dalam pengkajian tugas akhir ini. Tujuan petak percontohan ini untuk memberi contoh kepada petani agar cepat dalam menerima informasi dan teknologi yang diterapkan pada kegiatan pengkajian tugas akhir ini. Petak percontohan ini seluas $200 \mathrm{~m} 2$, dan dibagi menjadi dua blok. Blok pertama atau blok $A$ menerapkan pengendalian hama secara terpadu, sedangkan blok kedua atau blok B tidak menerapkan pengendalian hama secara 
terpadu. Jayasooriya dan Aheeyar (2016) mengatakan bahwa pembuatan petak uji coba penerapan PHT secara partisipatif dan dikembangkan paket PHT yang disederhanakan untuk pengendalian hama dan penyakit utama, juga membantu dalam mempopulerkan PHT dikalangan petani.

Berdasarkan hasil penelitian yang dilakukan oleh Gunawan et. al., (2015) yang meneliti pengaruh penerapan PHT dan pengendalian secara konvensional menjelaskan bahwa berat gabah kering panen (GKP) pada lahan konvensional lebih berat dibandingkan dengan lahan yang di terapkan PHT. Hal tersebut disebabkan adanya serangan hama walang sangit dan penyakit blast dan tidak dilakukan penanganan secara khsusus, terutama pemberian insektisidan dan fungisida. Namun, dampak positif dari penerapan PHT tersebut mengurangi populasi WBC, karena terdapatnya musuh alami terutama laba-laba. Berbeda dengan hasil penelitian yang dilakukan oleh Alam et al (2016a) menyatakan bahwa manajemen hama terpadu dan praktik petani keduanya memiliki efek signifikan pada jumlah malai padi, kelimpahan anakan yang sehat, dan persentase hama pengerek batang dan sundep cenderung sedikit. Selain itu praktik ini dapat memengaruhi berat dan hasil gabah. Kami menemukan kejadian hama pengerek batang dan sundep keduanya relatif lebih rendah di plot yang diterapkan PHT". Didukung dengan hasil penelitian lainya yang dilakukan oleh Alam et. al., (2016b) menyatakan bahwa praktik PHT dapat digunakan untuk pengendalian hama yang efektif dalam sistem pertanian padi, dimana keuntungan utama dari teknik ini adalah hasil panen meningkat seiring dengan meningkatnya ketahanan sistem pertanaman padi tersebut. Studi kami menunjukkan bahwa strategi PHT yang dirancang dengan baik dapat memiliki efek positif pada komponen hasil. Dalam penelitian kami, varietas padi BRRI Dhan 29 menghasilkan 7,3 - 7,5 ton / ha di petak-petak perlakuan PHT.

Berdasarkan beberapa hasil penelitian diatas, menggambarkan bahwa penerapan pengendalian hama terpadu dapat meningkatkan hasil, namun efeknya tidak langsung secara besar. Kenaikannya secara perlahan seiring meningkatnya sistem imunitas tanaman dan terbentuknya ekosistem yang seimbang. Keempat prinsip PHT (budidaya tanaman sehat, pemanfaatan musuh alami, pengamatan OPT secara berkala, petani sebagai ahli PHT) tersebut secara keseluruhan mengandalkan alam dalam sistem pengendaliannya.

\section{Strategi Peningkatan Kemandirian Petani}

Berdasarkan hasil pengukuran menunjukan bahwa tingkat kemandirian petani dalam penerapan pengendalian hama terpadu padi sawah sebagian besar $(52,5 \%)$ responden berada pada kategori sedang. Hal ini menunjukan bahwa harus adanya pengembangan terhadap kemandirian petani dalam penerapan pengendalian hama terpadu padi sawah. Kemudian faktor yang berpengaruh terhadap kemandirian petani yaitu peran kelompok tani, akan tetapi faktor lainnya pun bukan berarti tidak berpengaruh, namun hanya pengaruhnya saja yang tidak begitu besar.

Strategi yang digunakan yaitu bertujuan untuk meningkatkan kemandirian petani dalam penerapan pengendalian hama terpadu (PHT) padi sawah. Berdasarkan hasil analisis mengenai faktor internal (karakteristik) responden yaitu umur, tingkat pendidikan, lama berusahatani, luas lahan, pengetahuan yang menunjukan keadaan petani dengan ciri masing-masing, akan tetapi hal itu tidak terlalu memerlukan danya perlakuan khusus. Selain faktor internal petani, faktor eksternal pun seperti peran kelompok tani dan peran penyuluh tetap digunakan. Peran penyuluh tetap digunakan meskipun tidak berpengaruh secara signifikan, dikarenakan penyuluh merupakan salah satu agen perubahan (agen of change) dimana dalam hal ini penyuluh hanya berperan sebagai pendamping petani. Berdasarkan penilaian petani terhadap peran penyuluh pun memang sebagian besar $(70 \%)$ menilai rendah, hal ini lah yang menyebabkan peran penyuluh tidak berpengaruh, maka pada strategi ini peran penyuluh tetap digunakan dan lebih ditingkatkan tupoksinya sebagai penyuluh agar dapat berpengaruh dalam peningkatan kemandirian petani, karena penyuluh lah yang akan terus berperan dalam strategi ini kedepannya sebagai pendamping petani. Rancangan strategi dalam peningkatan kemandirian petani dalam 
penerapan pengendalian hama terpadu ini memiliki beberapa tahapan, diawali dengan input, proses, output, dan dampak/hasil. Seperti halnya strategi yang dilakukan oleh Indraningsih (2013) yaitu terdiri dari masukan, proses, keluaran, dampak.

\section{Input}

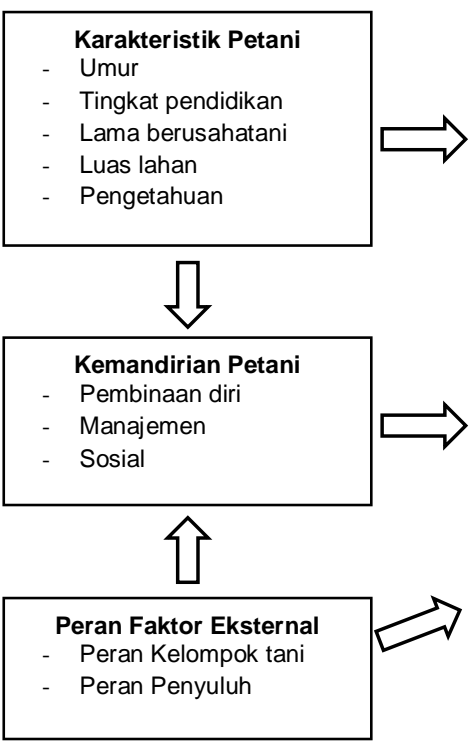

Proses

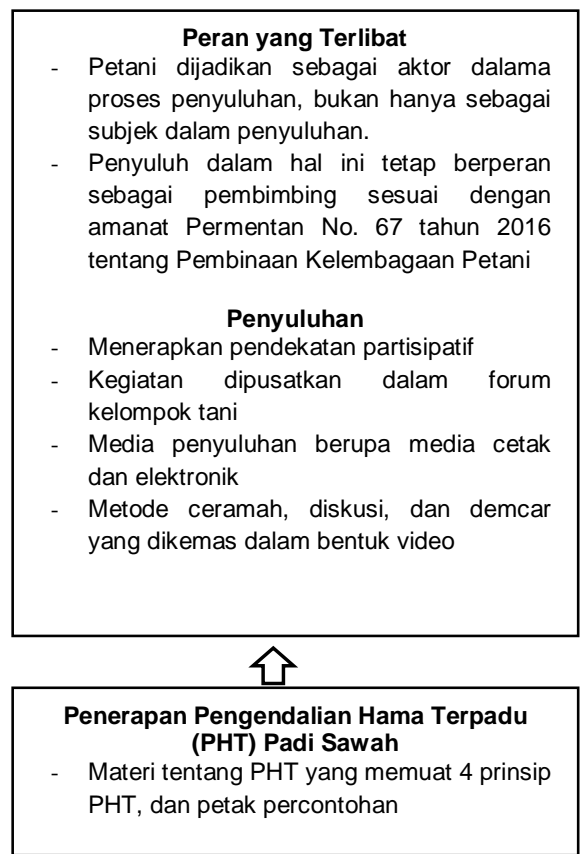

Output

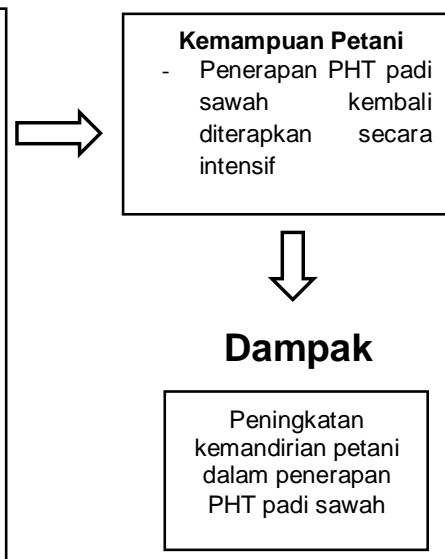

Gambar 1. Strategi Penyuluhan untuk Peningkatan Kemandirian Petani Dalam Penerepan Pengendalian Hama Terpadu Padi Sawa

Faktor internal dan eksternal digunakan sebagai input dalam strategi ini, dikarenakan hal tersebut menjadi dasar dalam penentuan strategi dan menentukan proses. Terutama faktor yang berpengaruh secara signifikan, yang memberikan peran dan pengaruhnya terhadap kemandirian petani. Selanjutnya proses tersebut lebih banyak dan dipusatkan dilingkup forum kelompok, hal ini dikarenakan kelompok memiliki pengaruh yang signifikan terhadap kemandirian petani. Kegiatan penyuluhan dan kegiatan lainnya dipusatkan diforum kelompok tani. Harapannya output yang dihasilkan petani lebih intensif dan progres dalam penerapan pengendalian hama terpadu. Kemudian dampak yang dihasilkan yaitu adanya peningkatan terhadap kemandirian petani dalam penerapan pengendalian hama terpadu.

\section{SIMPULAN}

Tingkat kemandirian petani dalam penerapan pengendalian hama terpadu (PHT) tanaman padi sawah 37,5\% tergolong kedalam kategori rendah, 52,5\% tergolong kedalam kategori sedang, dan 10\% tergolong kedalam kategori tinggi. Berdasarkan hal tersebut masih perlu adanya peningkatkan kemandirian, melalui kegiatan penyuluhan dan bimbingan secara intensif, guna untuk meningkatkan kemandirian petani dalam penerapan pengendalian hama terpadu. Faktor yang berpengaruh secara signifikan adalah peran kelompok tani.

Startegi yang dilakukan yaitu dengan mengunakan 4 tahapan yaitu input, proses, output, dan dampak. Proses penyuluhan dan kegiatan lainnya di pusatkan pada forum kelompok tani, dengan memposisikan petani sebagai aktor/pelaku dan penyuluh sebagai pendamping. 


\section{DAFTAR PUSTAKA}

Alam, Mohammad Zahangeer, Md. Manjurul Haque, Emran Hossain, Sabiha Binta hasan, Shahela Binte Hasan, dan Md. Sakhawat Hossain. 2016. Comparative Study of Integrated Pest Management and Farmers Practices on Sustainable Environment in the Rice Ecosystem. International Journal of Zoology: Vol. 2016 Article ID 7286040. Hindawi Publishing Corporation.

Aprolita, Siti Aminah, dan Djoko Susanto. 2008. Kemandirian Pembudidaya Ikan Patin di Lahan Gambut di Desa Tangkit Baru Kecamatan Kumpe Ulu Kabupaten Muara Jambil Provinsi Jambi. Jurnal Penyuluhan, Vol. 4, No. 2, HIm 126-134.

Astuti dan Honorita. 2014. Potensi Pemanfaatan Lahan Pekarangan sebagai Sumber Bahan pangan Lokal di Provinsi Bengkulu. Prosiding Seminar Nasional Hari Pangan Sedunia ke 33 "Optimalisasi Sumberdaya Lokal Melalui Diversifikasi Pangan Menuju Kemandirian Pangan dan Perbaikan Gizi Masyarakat Menyongsong Masyarakat Ekonomi ASEAN 2015". Pusat Sosial Ekonomi dan Kebijakan Pertanian, Kementerian Pertanian.

BPP Sukalarang. 2020. Programa Penyuluhan Pertanian Desa Sukalarang 2020. Sukabumi: Balai Penyuluhan Pertanian Kecamatan Sukalarang.

BPS. 2018. Kabupaten Sukabumi dalam Angka 2018. Sukabumi: Badan Pusat Statistik Kabupaten Sukabumi.

BPS. 2019. Kabupaten Sukabumi dalam Angka 2019. Sukabumi: Badan Pusat Statistik Kabupaten Sukabumi.

Budhi, G.S. dan M. Aminah. 2009. Faktor-faktor Dominan dalam Pembentukan Lemabaga Sosial. Forum Penelitian Agro Ekonomi, Vol. 27, No 1, HIm 29-41

Burhansyah, B. 2014. Faktor-faktor yang mempengaruhi Adopsi Inovasi Pertanian pada Gapoktan PUAP dan Non PUAP di Kalimantan Barat (Studi Kasus: Kabupaten Pontianak dan Landak). Informatika Pertanian, Vol. 23, No. 1, HIm 65-74.

Covey SR. 2010. The 7 Habbit of Highly Effective People. Bandung (ID): Bumi Aksara.

Elsiana, Sriroso Satmoko, dan Siwi Gayatri. 2018. Pengaruh Fungsi Kelompok Terhadap Kemandirian Anggota Pada Kelompok Tani Padi organik Di Paguyuban AlBarokah Desa Ketapang, kecamatan Susukan Kabupaten Semarang Jawa Tengah. Jurnal Ekonomi Pertanian dan Agribisnis (JEPA), Vol. 2, No. 2, HIm 111118.

Fadhilah M. L., B. T. Eddy, dan S. Gayatri. 2018. Pengaruh Tingkat Pengetahuan, Sikap dan Keterampilan Penerapan Sistem Agribisnis terhadap Produksi pada Petani padi di Kecamatan Cimanggu Kabupaten Cilacap. Jurnal Sosial Ekonomi Pertanian, Vol. 2, No 1, HIm 39-49.

Gunawan, Claudya Siktiana Eva., Gatot Mudjiono, dan Ludji Pantja Astuti. 2015. Kelimpahan Populasi Wereng Batang Coklat Nilaparvata lugens Stal. (Homoptera: Delphacidae) dan Laba-laba pada Budidaya Tanaman Padi dengan Penerapan Pengendalian Hama Terpadu dan Konvenional. Jurnal HPT, Vol. 2, No. 1, HIm 117-122.

Haque, Mirza Mobashwerul., Muhammad Hurmayun Kabir, dan Noushin Anjum Nishi. 2016. Determinants of Rice Farmer's Adoption of Integrated Pest Management Practices in Bangladesh. Journal of Experimental Agricultur International, Vol. 14, No 14 , HIm 1-6. 
Indraningsih, Kurnia Suci. 2011. Pengaruh Penyuluhan terhadap Keputusan Petani dalam Adopsi Inovasi Teknologi usahatani Terpadu. Jurnal Agro Ekonomi, Vol. 29, No.1, HIm 1-24.

2013. Faktor-faktor yang Mempengaruhi Kinerja Ushatani Petani Sebagai Representasi Strategi Penyuluhan Pertanian Berkelanjutan di Lahan Marjinal. Jurnal Agro Ekonomi, Vol. 31, No. 1, HIm 71-95.

Jayasooriya, H.J.C., dan M.M.M. Aheeyar. 2016. Adoption and Factors Affecting on Adoption of Integrated Pest Management Among Vegetable Farmers in Sri Lanka. Science Direct: Procedia Food Science 6, HIm 208-212.

Kementerian Pertanian Republik Indonesia. 2016. Peraturan Menteri Pertanian Republik Indonesia nomor 67/Permentan/SM.050/12/2016, Tentang Pembinaan Kelembagaan Petani. Jakarta: Kementan RI.

Khairunnisa, Amiruddin Saleh, dan Oos M Anwas. 2019. Penguatan Kelembagaan Petani Padi dalam Pengambilan Keputusan Adopsi Teknologi IPB Prima. Jurnal Penyuluhan, Vol 15, No. 1, HIm 89-96.

Lestari, Wahyu Puji., Diah Mardiningsih, dan Siwi Gayatri. 2018. Peran Kelompok Tani terhadap Tingkat Pengetahuan Petani Jambu Biji Getas Merah di Kelompok Tani Makmur Kecamatan Pagerruyung Kabupaten Kendal. Jurnal ilmu-ilmu Pertanian, Vol. 2, No. 1, HIm 84-93.

Muhidin, S. A., dan M. Abdurahman. 2007. Analisis Korelaasi, Regresi, dan Jalur dalam Penelitian. Pustaka Setia. Bandung.

Nuryanti, Sri dan Dewa K.S. Swastika. 2011. Peran Kelompok tani Dalam Penerapan Teknologi Pertanian. Forum Penelitian Agro Ekonomi, Vol. 29, No. 2, HIm 115128.

Prastia, D.H., Hariyanto, dan Eva Banowati. 2016. Pengaruh Pengetahuan Petani Kentang terhadap Pertanian Berkelanjutan di desa Kepakisan Kecamatan Batur. Jurnal Edu geography: Vol. 4 No. 3.

Rahaman, Muhammad Matiar., Khandkar Shariful Islam, dan Mahbuba Jahan. 2018. Rice Farmer's Knowledge of the Risk of Pesticide use in Bangladesh. Journal of Health \& Pollution, Vol. 8, No. 20, HIm 1-9.

Rahayu, Tri dan Rosda Malia. 2018. Pengaruh Kepemimpinan Ketua Kelompok Terhadap Tingkat Kemandirian Anggota Kelompok Di Gabungan Petani Organik (GPO) NyiSri Kecamatan Cianjur Kabupaten Cianjur. Agroscience, Vol. 8, No. 1, HIm 1-21.

Sari, Resti Yulanda., Roza Yulida, dan Eri Sayamar. 2016. Perbandingan Tigkat Pengetahuan Petani Sebelum dan Sesudah menggunakan Media Visual dan Media Audiovisual terhadap Petani di Kelurahan Telaga Samsam Kecamatan Kandis Kabupaten Siak. Jurnal Jom Faperta, Vol. 3, No. 1, HIm 1-11.

Setiawan, Satrio Adi. 2010. Pengaruh Umur, Pendidikan, Pendapatan, Pengalaman Kerja, dan Jenis Kelamin terhadap Lama Mencari Kerja Bagi tenaga kerja Terdidik di Kota Magelang. Skripsi. Universitas Diponegoro, Semarang. (Dipublikasikan)

Sholeh, Mohammad Shoiumus., Kustiawati Ningsih, dan Henny Susilawati. 2019. Analisis Efisiensi Teknis Penerapan Pengendalian Hama Terpadu (PPHT) Skala Kawasan pada Tanaman Padi (Oryza sativa. L) di Pademawu Barat, Pamekasan. JSEP, Vol. 12, No. 3, HIm 71-77.

Sukmaningrum, Adisti dan Ali Imron. 2017. Manfaat usia Produktif dengan Usaha Kreatif Industri Pembuatan Kaos pada Remaja di Gresik. Paradigma, Vol. 5, No. 3, 1-6.

Sumilah dan M. Ichwan. 2017. Analisis Pengaruh Pengetahuan Anggota Kelompok Wanita Tani terhadap teknologi Pemanfaatan Lahan Pekarangan di Kecamatan 
Barangin Kota Sawahlunto. Prosiding Seminar Nasional Agroinovasi Spesifik Lokasi untuk Ketahanan Pangan pada Era masyarakat Ekonomi ASEAN. Balai Pengkajian Teknologi Pertanian Sumatera Barat, HIm 460-468.

Sulistiyono, Luluk., Rudy C. Tarumingkeng, Bunasor Sanim, dan Dadang. 2008. Pengetahuan Sikap dan Tindakan Petani Bawang Merah dalam Penggunaan Pestisida (Studi kasus di Kabupaten Nganjuk Provinsi Jawa Timur). Jurnal Agroland, Vol. 15, No 1, HIm 12-17.

Toha. Moh, Achmad Musyadar. 2014. Kemandirian Petani dalam Proses Pemasaran Hasil Tanaman Karet di Desa Gunung Bungsu Kabupaten Kampar. Jurnal Penyuluhan Pertanian, Vol. 9, No. 1, HIm 7-20.

Wardani dan Oeng Anwarudin. 2018. Peran Penyuluh terhadap Penguatan Kelompok Tani dan Regenerasi Petani di Kabupaten Bogor Jawa Barat. Jurnal TABARO, Vol. 2, No. 1, HIm 191-200.

Wijaya, Muhammad Agung. 2018. Kemandirian Petani dalam Penerapan Pengendalian Organisme Pengganggu Tanaman (OPT) Terpadu pada Tanaman Kedelai (Glycine maz. L) Di Kecamatan Ciranjang Kabupaten Cianjur Provinsi Jawa Barat. KIPA. Sekolah Tinggi Penyuluhan Pertanian Bogor, Kota Bogor. 